medRxiv preprint doi: https://doi.org/10.1101/2020.04.20.20061861; this version posted April 22,2020 . The copyright holder for this preprint
(which was not certified by peer review) is the author/funder, who has granted medRxiv a license to display the preprint in perpetuity. It is made available under a CC-BY-NC-ND 4.0 International license .

\title{
Interleukin-6 blockade for severe COVID-19
}

Mathilde Roumier ${ }^{1}, \mathrm{MD}$, Romain Paule ${ }^{1}, \mathrm{MD}$, Matthieu Groh${ }^{1}, \mathrm{MD}$, Alexandre Vallée ${ }^{2}, \mathrm{MD}$, Félix Ackermann ${ }^{1}$, MD, for the Foch COVID-19 Study Group

\section{Affiliations:}

1. Department of Internal Medicine, Hôpital Foch, F-92151 Suresnes, France

2. Diagnosis and Therapeutic Center, Hypertension and Cardiovascular Prevention Unit, AP-HP, Hôtel-Dieu Hospital, Paris-Descartes University, Paris, France

\section{Corresponding author:}

Dr Félix Ackermann, Department of Internal Medicine, F-92151 Suresnes, France; tel: +33146252119; Fax +33146252620; f.ackermann@hopital-foch.com

\section{Abstract:}

In the context of COVID-19 pandemic and growing tensions worldwide regarding healthcare facilities, there is an urgent need for effective treatments likely to reduce the crunch of ICU beds. Following the assumption by Mehta and colleagues who exhorted physicians to screen patients with severe COVID-19 for hyperinflammation and investigate immunomodulatory drugs in this setting, we relate our short-term - yet promising - experience regarding IL6 blockade with tocilizumab in 30 selected patients of less than 80 years of age, $>5$ days of prior disease duration, severe (i.e. requiring strictly over $6 \mathrm{~L} / \mathrm{min}$ of oxygen therapy) rapidly deteriorating (i.e. increase by more than $3 \mathrm{~L} / \mathrm{min}$ of oxygen flow within the previous 12 hours) COVID-19-related pneumonia. By comparison with a control group of patients (matched for age, gender and disease severity using the inverse probability of treatment weighted methodology) that did not receive 
medRxiv preprint doi: https://doi.org/10.1101/2020.04.20.20061861; this version posted April 22, 2020. The copyright holder for this preprint (which was not certified by peer review) is the author/funder, who has granted medRxiv a license to display the preprint in perpetuity. It is made available under a CC-BY-NC-ND 4.0 International license.

tocilizumab. We demonstrate that, in highly selected patients, IL6 blockade could curb the "cytokine storm", prevent ICU admission and the requirement for mechanical ventilation. Notwithstanding the shortcomings of this retrospective small sample-size study, we believe that these preliminary findings support the fostering of research efforts in the fight against COVID-19-induced inflammation, especially before patients require admission to the ICU.

Manuscript word count: 711 words

Table: 1 ; Figure: 0

The pathophysiology of Corona Virus Disease-19 (COVID-19) is still unclear. Yet, in a subgroup of patients with life-threatening acute respiratory distress syndrome (ARDS), there is growing evidence that virally-induced pro-inflammatory cytokines (including Interleukin (IL)1 $\beta$, IL-6, tumor necrosis factor- $\alpha$, and granulocyte colony stimulating factor) lead to both hyperinflammatory and procoagulatory states at a late-stage of the disease $(1,2)$. Such findings are further corroborated by recent studies, which highlighted that high levels of C-reactive protein, IL-6 and D-Dimer upon admission were predictors of mortality $(3,4)$. In their recent Comment, Mehta and colleagues exhorted physicians to screen patients with severe COVID-19 for hyperinflammation and suggested that immunosuppressive and/or immunomodulatory drugs should be investigated in this setting (5). Here, we relate our short-term - yet promising - experience regarding IL6 blockade for severe COVID-19 with tocilizumab. 

medRxiv preprint doi: https://doi.org/10.1101/2020.04.20.20061861; this version posted April $22,2020$. The copyright holder for this preprint
(which was not certified by peer review) is the author/funder, who has granted medRxiv a license to display the preprint in perpetuity. It is made available under a CC-BY-NC-ND 4.0 International license .

Tocilizumab is mainly used worldwide for the treatment of rheumatoid arthritis, but other indications include refractory giant cell arthritis, idiopathic multicentric Castleman disease, and chimeric antigen receptor T-cell therapy-induced cytokine release syndrome (a condition that to some extent can mimic the clinical picture of COVID-19induced ARDS) (6). In the emergency context of the COVID-19 epidemic in France, an offlabel compassionate-use program of intravenous tocilizumab $(8 \mathrm{mg} / \mathrm{kg}$ at the discretion of treating physicians, renewable once in case of insufficient response to therapy) was started at Foch university hospital (Suresnes, France) for selected COVID-19 patients (per WHO criteria) of less than 80 years of age with severe (i.e. requiring $>6 \mathrm{~L} / \mathrm{min}$ of oxygen therapy) rapidly deteriorating (i.e. increase by $\geq 3 \mathrm{~L} / \mathrm{min}$ of oxygen flow within the previous 12 hours) pneumonia, high C-reactive protein levels and with $\geq 5$ days of prior disease duration. All patients provided informed consent prior to receiving tocilizumab and this program was approved by the local Institutional Review Board (approval number: IRB00012437).

Between March $21^{\text {st }} 2020$ and April $2^{\text {nd }} 2020,30$ patients (80\% males; median age: 50 years) were treated with tocilizumab, including 7 (23\%) in the setting of Intensive Care Unit (ICU) (Table 1). After a median (IQR) follow-up of 8 (6.0-9.75) days, and by comparison with a control group of patients (matched for age, gender and disease severity using the inverse probability of treatment weighted methodology with SAS software) (7) that did not receive tocilizumab, IL-6 blockade significantly reduced the requirement of subsequent mechanical ventilation (weighted OR: $0.42 ; 95 \% \operatorname{CI}[0,20-0,89] ; p=0,025$ ). Although unadjusted analysis showed a trend towards a reduction of mortality (OR: 0.25 95\%CI [0.05-0.95], $\mathrm{p}=0.04)$, statistical significance disappeared after weighted analysis. Last, when considering only 23 patients (and 16 controls) treated outside the ICU, treatment with tocilizumab significantly reduced the risk of subsequent ICU admission 

medRxiv preprint doi: https://doi.org/10.1101/2020.04.20.20061861; this version posted April $22,2020$. The copyright holder for this preprint
(which was not certified by peer review) is the author/funder, who has granted medRxiv a license to display the preprint in perpetuity. It is made available under a CC-BY-NC-ND 4.0 International license .

(weighted OR: 0.17; 95\%CI[0,06-0,48]; $p=0,001$ ). Overall, as of April $4^{\text {th }} 2020$, of the 30 patients treated with tocilizumab, 3 (10\%) had died, while $4 / 7$ (57\%) and 6/30 (20\%) were discharged from the ICU and from hospital, respectively. Overall, tocilizumab was well-tolerated, yet mild hepatic cytolysis $(n=2)$ and ventilator-acquired pneumonia $(n=1)$ were reported. Of note, 2 patients treated with tocilizumab also received a 10-day course of hydroxychloroquine (200mg tid) and azithromycin (250mg bid on day1 and qid thereafter), while 2 patients (that were not treated with tocilizumab) received high-dose $(\geq 1 \mathrm{mg} / \mathrm{kg} / \mathrm{d})$ methylprednisolone pulses.

In the context of COVID-19 pandemic and growing tensions worldwide regarding healthcare facilities, there is an urgent need for effective treatments likely to reduce the crunch of ICU beds. Concordant with the assumption by Mehta (5) and others (8), these data suggest that targeting IL-6 in highly selected patients with rapidly deteriorating pneumonia and high inflammatory parameters could curb the "cytokine storm", prevent ICU admission and the requirement for mechanical ventilation. These results are in line with the encouraging data reported by $\mathrm{Xu}$ and colleagues regarding the use of tocilizumab in COVID-19 (9) , but differ from those of Gritti and colleagues who treated more severe patients requiring non-invasive ventilation with siltuximab (another IL-6R-targeted therapy) (10). Notwithstanding the shortcomings of these retrospective small samplesize studies, we believe that these preliminary findings support the fostering of research efforts in the fight against COVID-19-induced inflammation, especially before patients require admission to the ICU. Evidently, the results of ongoing larger-scale prospective randomized-controlled trials evaluating tocilizumab (ChiCTR2000029765; NCT04320615), sarilumab (NCT04315298; NCT04324073) and siltuximab (NCTNCT04329650) are eagerly awaited. Moreover, other immunomodulatory treatment 
medRxiv preprint doi: https://doi.org/10.1101/2020.04.20.20061861; this version posted April 22, 2020. The copyright holder for this preprint (which was not certified by peer review) is the author/funder, who has granted medRxiv a license to display the preprint in perpetuity. It is made available under a CC-BY-NC-ND 4.0 International license .

strategies including high-dose corticosteroids, IL-1 blockade or JAK inhibition also deserve to be investigated.

\section{References}

1. Huang C, Wang Y, Li X, et al. Clinical features of patients infected with 2019 novel coronavirus in Wuhan, China. Lancet.2020;395:497?506.

2. Chen N, Zhou M, Dong X, et al. Epidemiological and clinical characteristics of 99 cases of 2019 novel coronavirus pneumonia in Wuhan, China: a descriptive study. Lancet.2020;395:507?13.

3. Ruan Q, Yang K, Wang W, et al. Clinical predictors of mortality due to COVID-19 based on an analysis of data of 150 patients from Wuhan, China. Intensive Care Med. 3 mars 2020; doi: 10.1007/s00134-020-05991-x. [Epub ahead of print].

4. Zhou F, Yu T, Du R, et al. Clinical course and risk factors for mortality of adult inpatients with COVID-19 in Wuhan, China: a retrospective cohort study. Lancet.2020;395:1054目62.

5. Mehta P, McAuley DF, Brown M, et al. COVID-19: consider cytokine storm syndromes and immunosuppression. Lancet. 2020;395:103304.

6. Lee DW, Gardner R, Porter DL, et al. Current concepts in the diagnosis and management of cytokine release syndrome. Blood.2014;124:188095.

7. Haukoos JS, Lewis RJ. The Propensity Score. JAMA.2015;314:1637?8.

8. Lescure FX, Bouadma L, Nguyen D, et al. Clinical and virological data of the first cases of COVID-19 in Europe: a case series. Lancet Infect Dis. 2020 Mar 27. pii:

S1473-3099(20)30200-0. doi: 10.1016/S1473-3099(20)30200-0. [Epub ahead of print].

9. Xiaoling $\mathrm{Xu}, \mathrm{Han} \mathrm{M}, \mathrm{Li}$ T et al. Effective treatment of severe COVID-19 patients 
medRxiv preprint doi: https://doi.org/10.1101/2020.04.20.20061861; this version posted April 22, 2020. The copyright holder for this preprint (which was not certified by peer review) is the author/funder, who has granted medRxiv a license to display the preprint in perpetuity. It is made available under a CC-BY-NC-ND 4.0 International license.

with tocilizumab. chinaXiv. submitted for publication 2020; chinaXiv:202003.00026v1.

10. Gritti G, Raimondi F, Ripamonti D, et al. Use of siltuximab in patients with COVID19 pneumonia requiring ventilatory support. medRxiv. 1 avr $2020 ; 2020.04 .01 .20048561$ 
medRxiv preprint doi: https://doi.org/10.1101/2020.04.20.20061861; this version posted April 22, 2020. The copyright holder for this preprint (which was not certified by peer review) is the author/funder, who has granted medRxiv a license to display the preprint in perpetuity. It is made available under a CC-BY-NC-ND 4.0 International license.

Table 1: Demographic, clinical, laboratory, radiographic findings and outcomes of the overall population

\begin{tabular}{|c|c|c|c|c|c|c|}
\hline & \multicolumn{3}{|c|}{ Unadjusted population } & \multicolumn{3}{|c|}{ Weighted Population } \\
\hline & $\begin{array}{c}\text { Treated } \\
\mathrm{N}=30\end{array}$ & $\begin{array}{c}\text { Untreated } \\
\mathrm{N}=29\end{array}$ & P-value & $\begin{array}{c}\text { Treated } \\
\mathrm{N}=30\end{array}$ & $\begin{array}{c}\text { Untreated } \\
\mathrm{N}=29\end{array}$ & P-value \\
\hline \multicolumn{7}{|l|}{ Outcomes } \\
\hline Invasive ventilation & $10(33.3)$ & $16(55.2)$ & 0.089 & $43.1 \%$ & $64.0 \%$ & 0.025 \\
\hline Death & $3(10.0)$ & $9(31.0)$ & 0.041 & $17.2 \%$ & $18.7 \%$ & 0.837 \\
\hline \multicolumn{7}{|l|}{$\begin{array}{l}\text { Parameters used for the } \\
\text { propensity score }\end{array}$} \\
\hline Age & $58.8(12.4)$ & $71.2(15.4)$ & 0.001 & $62.3(11.3)$ & $60.6(21.6)$ & 0.598 \\
\hline Female & $6(20.0)$ & $6(20.7)$ & 0.947 & $21.9 \%$ & $16.4 \%$ & 0.459 \\
\hline Baseline ICU hospitalization & $7(23.3)$ & $13(44.8)$ & 0.079 & $33.4 \%$ & $50.3 \%$ & 0.066 \\
\hline COPD & $4(13.3)$ & $7(24.1)$ & 0.284 & $15.1 \%$ & $16.0 \%$ & 0.888 \\
\hline Diabetes & $7(23.3)$ & $10(34.5)$ & 0.343 & $29.5 \%$ & $27.6 \%$ & 0.819 \\
\hline Obesity & $5(16.7)$ & $4(13.8)$ & 0.759 & $19.6 \%$ & $31.9 \%$ & \\
\hline NEWS 2 score & & & 0.786 & & & 0.734 \\
\hline score $\geq 7$ & $24(80.0)$ & $24(82.8)$ & & $83.3 \%$ & $85.6 \%$ & \\
\hline score $5-6$ & $6(20.0)$ & $5(17.2)$ & & $16.7 \%$ & $14.4 \%$ & \\
\hline C-reactive protein $(\mathrm{mg} / \mathrm{L})$ & $\begin{array}{c}189.0 \\
(104.4)\end{array}$ & $\begin{array}{c}167.4 \\
(106.8)\end{array}$ & 0.426 & $\begin{array}{c}186.7 \\
(112.7)\end{array}$ & $\begin{array}{l}160.8 \\
(93.7)\end{array}$ & 0.179 \\
\hline $\begin{array}{l}\text { Eosinopenia } \\
\text { Time between }\end{array}$ & $21(70.0)$ & $25(86.2)$ & 0.129 & $78.8 \%$ & $88.7 \%$ & 0.146 \\
\hline $\begin{array}{l}\text { hospitalization and the need } \\
\text { for }>6 \mathrm{~L} / \mathrm{min} \text { of oxygen therapy } \\
\text { (hours) }\end{array}$ & $1.8(3.1)$ & $4.1(11.8)$ & 0.263 & $1.5(2.6)$ & $2.4(8.5)$ & 0.428 \\
\hline \multicolumn{7}{|l|}{ Comorbidities } \\
\hline Hypertension & $6(20.0)$ & $18(62.1)$ & 0.008 & & & \\
\hline Cardiovascular disease & $4(13.3)$ & $10(34.5)$ & 0.053 & & & \\
\hline Cerebrovascular disease & $0(0.0)$ & $3(10.3)$ & 0.071 & & & \\
\hline Chronic kidney disease & $4(13.3)$ & $5(17.2)$ & 0.676 & & & \\
\hline HIV & $2(6.7)$ & $1(5.6)$ & 0.877 & & & \\
\hline Immunosupressive therapy & $4(13.3)$ & $3(15.0)$ & 0.868 & & & \\
\hline \multicolumn{7}{|l|}{ Clinical findings } \\
\hline BMI $\left(\mathrm{kg} / \mathrm{m}^{2}\right)$ & $27.6(3.8)$ & $25.5(3.9)$ & 0.183 & & & \\
\hline $\begin{array}{l}\text { Time of first symptoms to } \\
\text { Tocilizumab onset (days) }\end{array}$ & $14.1(3.5)$ & .. & .. & & & \\
\hline \multicolumn{7}{|l|}{ Paraclinical findings } \\
\hline Positive PCR for SARS-CoV2 & $29(96.7)$ & $29(100)$ & 1.000 & & & \\
\hline Lymphopenia & $23(82.1)$ & $17(85.0)$ & 0.793 & & & \\
\hline Ferritin $(\mu \mathrm{g} / \mathrm{L})$ & $\begin{array}{c}2682.8 \\
(3753.2)\end{array}$ & $\begin{array}{l}1827.9 \\
(1221.2)\end{array}$ & 0.391 & & & \\
\hline D-dimer (mg/L) & $\begin{array}{c}3712.8 \\
(5836.4)\end{array}$ & $\begin{array}{c}1880.5 \\
(2162.7)\end{array}$ & 0.335 & & & \\
\hline $\begin{array}{l}\geq 50 \% \text { lung involvement on } \\
\text { CT-scan }\end{array}$ & $18(85.7)$ & $6(85.7)$ & 1.000 & & & \\
\hline
\end{tabular}

Data are n (\%) and mean (SD). P-values were calculated using Mann-Whitney U test, chi-square test or Fisher's exact test, as appropriate. COPD = chronic obstructive pulmonary disease. CoV = Coronavirus. CT = computed tomography. ICU= Intensive Care Unit. NEWS= National Early Warning Score. PCR = polymerase chain reaction. SARS = Severe Acute Respiratory Syndrome. 